\title{
The Effects of Top Management Team External Ties and Board Composition on the Strategic Choice of Late Movers
}

Jae Wook Yoo

Richard Reed

Cleveland State University, r.reed68@csuohio.edu

Follow this and additional works at: https://engagedscholarship.csuohio.edu/bus_facpub

Part of the Organizational Behavior and Theory Commons

How does access to this work benefit you? Let us know!

\section{Publisher's Statement}

NOTICE: this is the author's version of a work that was accepted for publication in Long Range

Planning. Changes resulting from the publishing process, such as peer review, editing, corrections, structural formatting, and other quality control mechanisms may not be reflected in this document. Changes may have been made to this work since it was submitted for publication. A definitive version was subsequently published in Long Range Planning (2013); 10.1016/j.Irp.2013.08.002

\section{Original Published Citation}

Yoo, J. W., Reed, R. (2013). The Effects of Top Management Team External Ties and Board Composition on the Strategic Choice of Late Movers. Long Range Planning, pp. 1-12.

This Article is brought to you for free and open access by the Monte Ahuja College of Business at EngagedScholarship@CSU. It has been accepted for inclusion in Business Faculty Publications by an authorized administrator of EngagedScholarship@CSU. For more information, please contact library.es@csuohio.edu. 


\title{
The Effects of Top Management Team External Ties and Board Composition on the Strategic Choice of Late Movers
}

\author{
Jae Wook Yoo, Richard Reed
}

Introduction

Ever since Berle and Means ( 1932) discussed the separation of ownership and management in the "modern corporation," it has been accepted that the role of the board of directors is to act as fiduciaries for the owners. As such, shareholders have entrusted the board to monitor and control managers to minimize agency problems. Arguably, that trust was misplaced. After the problems of misleading financial disclosures which erupted in the late 1990s and early 2000s (Wintoki, 2007), and following arguments that have long been made in the governance literature (Fama, 1980; Fama and Jensen. 1983; Jensen and Meckling. 1976), there were calls by stock-exchange officials to increase the number of outsiders on boards and to separate the roles of CEO and chairman. Despite the soundness of the theoretical arguments which link both of those actions with improved decision-making and consequent firm performance, empirical research has not produced clear support for either (Dalton et al., 1998: Golden and Zajac, 2001: Langevoort, 2001). Methodological issues aside, that outcome likely reflects the fact that the research has focused on main effects, rather than digging more deeply into behavioral and interactive effects between the board and top managers (Daily et al., 2003).

Judge and Zeithaml (1992) found that boards could be involved in the process of formulating strategic decisions, and Westphal (1999) showed how boards could influence strategic decision-making through advice-giving interactions with CEOs (please also see O'Neal and Thomas, 1999; Westphal and Fredrickson, 2001: Wu, 2008). More recent research has focused on the idea of collaboration between the board and management in deciding strategy (e.g., Hendry et al., 2010; Zhang et al.. 2011). In many respects, that thinking blurs the line between agent and fiduciary. In other research on governance, it has been assumed - either implicitly or explicitly - that boards exercise relatively little independent influence over the firm's strategic direction (Baysinger and Hoskisson, 1990; Johnson et al.. 1996: Zahra and Pearce, 1989). Rather than directing strategic decisions, outside directors are thought to support managers by co-opting financial institutions, helping to avoid hostile takeovers, and perhaps providing information and expertise which aids in the implementation of management's strategy, without determining the strategy itself (e.g., Davis et al., 1994: Mizruchi, 1996). In reviewing this literature, Finkelstein and Hambrick (1996) noted that behavioral perspectives on boards have been "virtually uniform" in their assumption that "boards of directors are not involved in strategy formulation."

Clearly, some boards get involved in strategy making. but the preponderance of evidence supports the position of Finkelstein and Hambrick. Thus, if the board's role is primarily one of monitoring and control, and direct beneficial effects on strategy are unconfirmed, then the question remains: do interaction effects between the board and top management team (TMT) have an effect on strategy selection within the context of monitoring and control? in this work, we theorize about and test interactions between top managers and the board, but retain the agency perspective that a key function of the board is monitoring and control. Our work is thus based on the premise that managers will seek to benefit themselves at the expense 
of possible returns to owners. Therefore, the job of the board is to prevent that from happening by making sure the best strategy for shareholders is selected, which may not be the one managers prefer.

As a baseline, we start by establishing how TMT experience affects strategy selection. We then go on to address the issue of interaction by asking whether or not board composition and consequent experience, relative to management experience, affects strategy selection. Clearly, this is an issue of managerial risk preference versus board power, so we also take into account the separation of CEO and chair roles. What we discover is that interaction effects do occur. The more outsiders there are on the board, the more likely it is managers will be pushed away from their comfort zone in strategy selection. The implication of this is that board monitoring and control in and of itself is insufficient to protect the interests of the principals. Instead, managing the relationship between board structure, leadership structure, and top-management-team experience is key to reducing agency problems.

\section{Background and hypotheses}

Examining interaction effects between the board and TMT is complex, so for the sake of methodological parsimony, we elected to focus on the strategy of late movers for our dependent variable. First movers are firms that gain technological leadership through radical or architectural innovations; gain control over scarce resources; and/or, manage to lock in customers (Lieberman and Montgomery, 1988). Such game-changing innovations create new industries, or at the least affect the structure of an existing industry, as does control over resources and customers. In any case, new or existing competitors end up following the leader. Like first movers, late movers can use a variety of business level strategies and tactics, but because their actions can be explained relative to the actions of first movers, our dependent variable reduces measurement and complexity issues. Late-mover strategy is described in terms of a continuum of resources ranging from those that are similar to those of first movers (imitation), to those which are different (substitution) (Celetkanycz and Hambrick, 1997; Yon et al., 2009). Because of the ability of first movers to attract and secure economic rents, they have been the focus of much research attention. Less attention has been paid to the followers, even though they are more numerous. Although the focus of this work is on the interaction effects between the board and the TMT, an additional benefit of our research is that it heips redress the balance between research on first movers and late movers. In the following discussion, we start by briefly describing latemover strategy before going on to develop our hypotheses on TMT strategic choice and board effects.

\section{Late-mover strategies}

First-mover advantage has been described in terms of its drivers (enablers), which include resources and capabilities, isolating mechanisms, and environmental factors such as the pace of market and technological evolution (Suarez and Lanzolla, 2007). Despite this, some late movers are able to replicate or surpass a first mover's advantage by copying its unique practices or technologies, or by finding a more effective or efficient way of organizing and coordinating productive activities. Thus, threats to first movers arise from the use of resource imitation and resource substitution by late movers (Yoo et al., 2009). Here, a resource - imitation strategy is defined as the reproduction or copying of a first mover's resources in order to duplicate their competencies. For example, Miller's and Coors's brewing skills allowed them to duplicate Rheingold's innovation of light beer; and, GE's production skills being comparable to EMI's meant GE was able to imitate and eventually overcome EMI's lead in CAT scanners (Haunschild, 1994; Hunt, 2000: Schnaars. 1994). By contrast, a resource - substitution strategy is defined as the use of alternative resources to circumvent first-mover competencies. According to Dierickx and Cool (1989), a successful resource substitution by late movers will render the original asset stocks of first movers obsolete witness Canon's challenge to Xerox as a classic example of resource substitution, when Canon substituted qualitymanufacturing skills for Xerox's extensive technical-service capabilities (Dierickx and Cool. 1989; Porter and Ishikura, 1983; McEvily et al., 2000).

\section{TMT external ties and the strategic choice}

The upper-echelons perspective emphasizes the attributes of top managers as a team. because strategic decisions are often made and implemented through dynamic processes wherein managers interact, consult and debate with each other (Cyert and March, 1963: Daily and Schwenk, 1996; March and Simon. 1958; Gioid and Chittipeddi, 1991: Woiceshyn, 2009). The perspective begins with the premise that strategic decisions are made under conditions of information overload and ambiguity. Drawing from behavioral decision-theory, Hambrick and Mason (1984) argued that top managers cope with the inherent complexity of strategic decision-making by referring to their pre-existing beliefs about appropriate strategic behavior, and that these scripts and schemas are shaped by prior experience (Hambrick and Mason, 1984). Furthermore, several studies suggest that boundary-spanning activities appear to influence pre-existing beliefs of top management, and thus impact the strategic decisions in firms (e.g., Geletkanycz and Hambrick. 1997: Hatnschild, 1993). Research findings have shown that the external ties of top managers are an important means by which executives scan their business environment, and gain firsthand insight into other organizations' activities. But, in an attempt to economize on information search procedures, executives tend to rely on established channels to acquire information for insight into plausible alternatives.

We know that top managers exist in a social world, and that social embeddedness affects the major activities of firms and, as some recent research shows, it can have an effect on firm performance (Granovetter. 1988; Geletkanycz and Bovd. 2011 ). 
Managers can learn to better perceive and interpret, and appreciate more, their organization's task and general environments, by interacting with individuals and groups outside the organization to obtain valuable information from the task and general environments. They create social capital that is obtained from "cooperative exchanges" between the parties in social networks, and thus themselves become a valuable resource to their organization. According to D'Aveni (1990), if organizations or society are in the capitalist system, good relationships with outside parties may help organizations establish a competitive advantage and perform efficiently (please also see Adams, 1976; Burt, 1983: Coleman, 1988).

Information gained in these boundary-spanning activities of top managers may reinforce their existing perspectives or may expose them to new ideas and opportunities (Adans, 1980: Aldrich and Herker, 1977). The key to this distinction is the location of outside contacts, whether they inhabit the same operating environment or different ones. Contacts who share the same operating environment can provide information which helps expand a manager's own knowledge base. By contrast, contacts operating in other environments, such as other industries, expose managers to new ideas. Consistent with those arguments, different types of external ties of top managers - "intra-industry ties," defined as top managers' boundaryspanning relations inside their industry, and "extra-industry ties," defined as their boundary-spanning relations outside of their industry - have been shown to have different effects on the strategic outcomes of firms.

The ties to entities within the industry subject top managers of firms to an abundance of information about the successful practices common in that industry. Thus, there is a commonality which characterizes the perceptions of managers operating within the same industry. In particular, strategic and environmental information drawn from intra-industry sources bears a marked similarity to top managers' own knowledge and perceptions of the environment and opportunities within it. Labeling these common views "shared recipes," Spender (1989) suggested they emerge as a function of managers' similar experiences amassed through industry tenure (please also see Schefczyk and Gerpott, 2001). Therefore, per previous work, coupled with the homogenizing influences that emerge in social interaction, we can deduce that strong intra-industry ties of the TMT are likely to produce a preference for imitation of the successful market leader in the industry. Using precedent established in prior literature on the external ties of top managers (Child and Smith. 1987; Pfeffer and Salancik, 1987), where the total number of intra-industry importations (i.e., hiring top managers from inside the focal industry) and trade association ties (i.e., top managers' participation in trade organization) are used to measure the degree of intra-industry ties of the TMT, it may be expected that:

H1a: The greater the number of top managers hired from inside the focal industry, the more likely the adoption of resourceimitation strategies by late movers.

$H 1 b:$ The greater the number of top managers participating in trade associations, the more likely the adoption of resourceimitation strategies by late movers.

While ties to entities inside the industry expose top managers of late movers to the information about first movers, extraindustry ties (i.e., linkages to entities operating outside of the firm's industry) increase top managers' exposure to information that deviates from practices common in the focal industry. Extra-industry contacts do not rely on the same frame of reference. As already noted, their views of the environment, business practices, and even goal setting are more likely shaped by different experiences and diverge from those in the focal industry. Consequently, extra-industry referents of top managers offer them models which expand the range of strategic options. Again, following precedent, we use the total number of extra-industry importations (i.e., hiring top managers from outside the focal industry) and professional association ties (i.e., top managers' participation in professional associations) to represent the extra-industry ties of the TMT, and hypothesize that the TMTs extra-industry ties are positively associated with a resource-substitution strategy by late movers:

H2a: The greater the number of top managers hired from outside the focal industry, the more likely the adoption of resourcesubstitution strategies by late movers.

H2b: The greater the number of top managers participating in professional associations, the more likely the adoption of resource-substitution strategies by late movers.

\section{Board independence and the strategic choice}

A board of directors is a group of individuals elected to represent shareholders' interests via oversight and guidance of management (Seward and Walsh. 1996). The typical board has a mix of inside and outside directors. "Inside directors" are senior employees of the company, such as the CEO. "Outside directors" may be executives of other firms, mainly outside the focal industry, or, not untypically, they can be full-time professional directors who hold positions on the boards of several companies in various industries. Their views of the environment, business practices, and even goal setting are shaped by different experience and are likely to diverge from those prevalent in the focal industry. This heterogeneity in experience and knowledge equates to Harrison and Klein's work (2007) on diversity in organizations, where they deduced that, while differences in knowledge, experience and information can improve decision quality, creativity and flexibility, they can also produce task conflict. They also deduced that differences in position and opinion would reduce cohesiveness and lead to more distrust and conflict. In other words, the differences in experience and knowledge between board members and the TMT will lead to disagreement, and then, assuming the board is willing to exert power in their monitoring and control function, the views of board members will emerge as dominant. Management's preferred strategy will be modified to one that reflects 
outside board members' experience in other industries, and, all else being equal, will then equate to a resource-substitution strategy rather than imitation.

Balance of power in favor of the board has been linked to primacy of the monitoring role, a higher ratio of outside to inside directors, and separation of the chair and CEO roles (Kor. 2006; Mellahi, 2005; Morck er al., 1989). Westphal and Zajac (1995) have shown that relative TMT/board power can predict whose preferences are realized in selecting a successor CEO, while Golden and Zajac (2001) have reported that power influences the board's impact on strategic change. Despite the nonconclusive empirical findings on the performance effects of separating the roles of CEO and chairman, the agency view that board independence can be improved by separating CEO and board chairperson duties remains compelling. As argued above, boards can modify management's preference on strategy, which is especially true when board members are independent of the CEO's influence (Colden and Zajac, 2001: Westphal and Zajac, 1995). Thus, when board chairperson duty is assigned to an outside and independent board member, rather than the CEO, the potential for choosing a strategy of resource substitution over resource imitation is enhanced. Therefore, we hypothesize that:

H3a: After controlling for the effects of TMT's external ties, the ratio of outsiders on the board is positively associated with the adoption of resource-substitution strategies by late movers.

H3b: After controlling for the effects of TMTs extemal ties, the separation of CEO and board chairperson duties is positively associated with the adoption of resource-substitution strategies by late movers.

\section{Interaction effects of the TMT's external ties, board independence, and strategic choice}

Central to agency theory is the idea that managers will seek to benefit themselves by securing the maximum number of perquisites available. Somewhat less prominent, but equally important, is the idea that managers will select strategies and tactics which protect their employment-capital (Fama, 1980). Contrary to the notion of taking actions that produce gains from perquisites, protection of employment capital is driven by risk avoidance, whereby managers will prefer to implement safe strategies that provide safer but suboptimal returns. Like the well-publicized inflation of pay and bonuses which occurred in some organizations in the early part of this century, and which resulted in lengthy prison sentences for some executives, selecting safe strategies with suboptimal returns is also an agency problem. Therefore, assuming the board is performing its monitoring and control duties, it should take action to stop managers from protecting themselves at the expense of the principals.

Reflecting the arguments leading up to Hypotheses 1 and 2, managers will tend to select strategies that fit with their experience and knowledge. Thus, for managers with intra-industry experience and connections, they will seek to avoid the unknown and reduce risk to their employment capital by adopting a strategy of imitation, whereas managers with experience and knowledge from other industries will feel safer with different, resource-substitution strategies. Reflecting the arguments leading up to Hypothesis 3 , and within the context of monitoring and control, boards which have more outsiders and more power likely will question the motives of managers for adopting a given strategy. If the board perceives a motivation of protection of managerial employment capital, rather than maximizing returns to shareholders, they should press for a modified strategy. Thus, the interaction between board experience, knowledge and power, and managerial experience and knowledge, will result in managers who prefer low-risk imitation being encouraged to adopt resource substitution, and those who prefer low-risk substitution being encouraged to adopt imitation. All else being equal - such as previous firm performance - we may expect that:

H4a: For TMTs with managers hired from inside the focal industry, the higher the proportion of outside directors the lower will be the tendency of late movers to adopt resource-imitation strategies.

H4b: For TMTs with managers participating in trade associations, the higher the proportion of outside directors the lower will be the tendency of late movers to adopt resource-imitation strategies.

H5a: For TMTs with managers hired from outside the focal industry, the higher the proportion of outside directors the lower will be the tendency of late movers to adopt resource-substitution strategies.

H5b: For TMTs with managers participating in professional associations, the higher the proportion of outside directors the lower will be the tendency of late movers to adopt resource-substitution strategies.

\section{Methods}

Sample and data

The empirical setting for this study is the computer-equipment industry, which is characterized by rapid technological and managerial change and a highly competitive market. Also, there is a wealth of industry-and firm-specific information which allows us to identify the strategic actions of late movers (Angel and Engstrom, 1995: Lee et al., 2000: Schoenecker and Cooper; 1998). We collected data for the years 1986 to 2002. In the mid 80s, the Securities and Exchange Commission proposed that the New York Stock Exchange pressure firms to have audit committees made up entirely of outside directors. Consequently. 
the number of independent outsiders in board composition has been rising (Kesner, 1988; Patton and Baker, 1987). The mid80 s also marked the point at which a stream of significant new product introductions started to occur in the computer industry.

The initial sample, which was comprised of the largest publicly-traded U.S. firms in the computer industry, was identified from the cross-reference volume of Dun and Bradstreet's Reference Book of Corporate Management; analysts' surveys reported in Standard and Poor's Industry Surveys; and, Standard E' Poor's Register of Corporations, Directors and Executives from 1986 to 2002, yielding an initial sample of 95 firms. Large firms typically have well-established governance mechanisms, which makes them appropriate for testing the hypotheses in this work. Consistent with observations that Standard Industry Classification (SIC) codes are helpful in resolving the problem of industry boundary definition, our sample was generated by identifying firms with primary SIC codes at the 4-digit level. The similarity of the major activities of these firms was confirmed by checking Hoover's Handbook of American Business, and 10-K SEC filings from 1986 to 2002.

All information for the TMT, including external ties, was drawn from Dun and Bradstreet's Reference Book of Corporate Management, Standard and Poor's Register of Corporations, Directors and Executives, as well as 10-K and Proxy Statements for each year of the study period. Per convention, the TMT is defined as all individuals with titles, including senior vice president and above (e.g., president, COO, CEO) (Carpenter and Fredrickson, 2001; Goll et al., 2001). The average team size was 6.3. The data on board composition (i.e., separation of the CEO and board chair position, and the ratio of outsiders) were obtained from Standard and Poor's Register of Corporations, Directors, and Executives for each year of the study period. Resource profiles were established using data from COMPUSTAT. In the process of merging TMT and resource-profile information, the sample was limited to first and late movers which had data available in COMPUSTAT. Because firms went public in different years, and not all of them continued to operate through 2002, the sample did not include an equal number of firms for each year.

\section{Measures}

\section{Dependent variable}

To minimize validity concerns, where possible we have adopted methodologies established and validated in extant research. Per existing studies on market-entry strategies, first movers are those firms that introduced a radically new product or service which exploited a technological discontinuity. That introduction is a special case of significant and proactive innovation by first movers, which has been identified as a source of first-mover advantage. On the other hand, late movers are firms that subsequently introduce a competing product or service (Nelson and Winter, 1982: Suarez and Lanzolla, 2007: Tellis and Golder, 1996).

First and late movers in the computer industry were identified from Predicasts FES Index United States. Using LexisNexis, we first identified all introductions of "pioneering new-product or service categories based on significant innovation" for each year of the study period (e.g. Ferrier and Lee, 2002; Kor: 2003: Zantout and Chaganti, 1996). The selection of first and late movers was confirmed from articles which appeared in the trade or business press, and from industry monographs that detailed the history of the industry and also identified new products as innovative and pioneering. Again, this approach is consistent with studies on market-entry strategies. There were 30 new-product or service innovations by nine first movers over the 16-year time span from 1986 to 2001.

The managers of late-mover firms decide on the extent to which they will deviate from the resource position of the industry's first mover. Thus, again following precedent, to measure late mover strategy, the resource deployments of late movers were compared to those of first movers. A resource profile closer to that of a first mover indicates a strategy based mostly on resource imitation, while a resource profile which is substantially different indicates a greater reliance on a strategy of resource substitution. This approach is consistent with the argument that the resource-based view and market-entry strategies are conceptually related. It is also consistent with the view that strategy is an observed pattern in an array of actions, which is reflected in resource deployments across the key functional activities of marketing, production, R\&D and finance. It is through this deployment of resources that firms compete in their industries (Hambrick, 1980: Murthi et al., 1996).

Empirical research dealing with strategic choice and TMTs has measured resource deployments in terms of advertising intensity (advertising expense/sales); capital intensity (fixed assets/number of employees); plant and equipment newness (net plant and equipment/gross plant and equipment); R\&D intensity (R\&D expense/sales); overhead efficiency (selling, general and administrative expense/sales); and, financial leverage (total debt/equity). Advertising intensity, capital intensity, plant and equipment newness, and R\&D intensity are all indicators of the allocation and management of firm resources across marketing, innovation and capacity-expansion activities; overhead efficiency captures expense structure; and, financial leverage reflects an organization's approach to capital management. Together, these ratios provide an overview of a firm's competitive profile (Schendel and Patton, 1978). Using these measures we assessed the resource profiles of first and late movers for each year of the study period, and calculated the absolute difference of each late mover's scores from each first mover's score, after standardizing. Then, following Finkelstein and Hambrick's (1990) methodology, we summed up all differences from the six measures to create a single, composite indicator of strategy.

By using a one-year lagged design, delays between the time when top managers participate in external interactions which affect their strategic thinking, and then engage in decision-making activities, are accounted for. Thus, our analysis is designed to take into account the effects of the TMT's external ties and board composition at time $t$ on firm strategic-choice at time $t+1$. Because of this lagged design, strategy was measured up to and including 2002, but the time frame for TMT ties and board 
independence was curtailed at 2001. While a longer time lag can be used (e.g., a two-year lag), top managers are most likely to recall and use information derived from recent interactions (Haveman. 1992; Virany et al., 1992). Additionally, not only are each of the resource dimensions used in this study amenable to change in a relatively short time, but also, in a dynamic competitive industry (e.g., computer equipment), it is unlikely that late movers could afford to wait two years or more.

\section{Independent variables}

Again following precedent, we rely on the total number of intra-industry importations and trade association ties to measure the intra-industry ties of the TMT. Imported top managers bring with them knowledge gained through personal experience with other firms' policies and practices. Given that over time their attention becomes increasingly inwardfocused, we have adopted Finkelstein and Hambrick's (1990) solution, which limited TMT intra-industry importation to the previous 10 years and adjusted for recency by making the adjustment ( 10 - firm tenure at the focal firms)/10. For example, a top manager who had been with the focal firm for six years received an importation score of 0.4 .

Trade associations are established and funded by businesses which operate in a specific industry. Typically, their function is to promote standardization across the goods offered, and to advertise and lobby on behalf of businesses in the industry. There are over 7000 trade associations in the U.S., including such groups as The Aluminum Association, The Food and Beverage Association, and The Electronics Industries Alliance. Given that trade associations constitute a forum for the establishment of industry rules of behavior, they tend to be influenced by the first movers (DiMaggio and Powell, 1983; Herman, 1981). Managers involved with trade associations will thus be exposed to the information on and the influences of first movers, to their strategies and tactics, and which resources are crucial for success. We therefore used a count of the number of trade association in which top managers participated as a measure of intra-industry ties.

We measured extra-industry importation in the same way as intra-industry importation; that is, a count of extra-industry hires added to the TMT within the previous 10 years, adjusted for recency: $(10$ - firm tenure at the focal firms)/10. The memberships in organizations which draw top managers from diverse industries are primary mechanisms for the exchange of unique information among organization leaders. Thus, participation in professional associations has been considered an important means by which to gain new ideas and perspectives. Such affiliations allow top managers to interact openly with others working in a similar professional capacity (Aldrich and Pfeffer, 1976; Scott, 198.5). To measure professional-association ties, we counted all top managers' memberships in industry-spanning associations, such as The Conference Board, and Business Roundtable, for each year of the study period. Because the number of external ties covaries with top management team size, we normalized the data by dividing the number of ties by team size.

Empirically, it is apparent that there are variations in the classification of board members and the measurement of their dependence on the CEO. Daily et al. (1999) identified over twenty-five separate operationalizations of director dependence on the CEO in the governance literature. However, using the various operationalizations, they could not find support for a single construct that was indicative of director dependence on the CEO. Because of these ambiguities, we use the simpler dual classification, consistent with that used in a number of previous studies (e.g., Hermalin and Weisbach, 1991; Molz. 1988). The officers of the company who also are directors are considered as inside directors, and all others are assumed to be outside directors. Finally, the separation of the CEO and board chair position is measured with a dummy variable which takes the value of one, if the CEO of the firm is not the board chair at the same time (Sundaramurthy er al., 1977).

\section{Control variables}

Because TMT experience is important for strategy formulation, we controlled for TMT tenure using the mean number of years members of the TMT had spent in the firm. Also, because firms often have different resources and perform differently at different stages of development (e.g., startup vs. mature) we also controlled for firm age, measured as the number of years since the firm was founded. In addition, we controlled for firm size, measured as the log of total assets, because it has been identified in various studies as a factor that impacts strategic choice (Marlin et al., 2004).

We also controlled for the degree of diversification, because managers in diversified firms may have access to ideas from their colleagues for which managers in undiversified firms would need extra-industry contacts. We used a Rumeltian (1974) approach to measuring diversification: firms with $70 \%$ or more of revenues from a single four-digit industry were classified as single/dominant, whereas those with less than 70\% were classified as diversified. Because of the lagged nature of the dependent variable (strategic choice at $t+1$ ), strategy at time $t$ was introduced as an additional control. Such controls are necessary when datasets are slow to change over time, or when they may be influenced by unobserved variables (Rumelt, 1974). Current year control of lagged variables reduces the likelihood of model misspecification (known to generate biased and inconsistent estimates) and facilitates better assessment of the effects attributable to the independent variables studied. They are also important in clarifying the temporal order of measures, and thus rule out the potential problem of reverse causality (Eisenmann, 2002; Sanders and Boivie, 2004).

\section{Analysis}

The unit of analysis was the firm. The final sample consisted of 724 responses by late movers to the pioneering moves of first movers. The hypotheses were tested using multiple regression. Given that interaction effects are meaningful only if the 
interaction terms give a significant contribution over and above the direct effects of the independent variables, Hypotheses 4 and 5 - which posit the interaction effects of the TMTs external ties and board-outsiders ratio on the strategic choices of late movers - were tested using a moderated-multiple-regression design, as recommended in the literature (judge et al.. 1982; Richey et al., 2004: Wiklund and Shepherd, 2003). The data were corrected for autocorrelation by applying the CochraneOrcutt transformation (Kmenta, 1986). Also, the Durbin and Watson (1950, 1951) statistic (1.9) was examined to verify that autocorrelation was not a problem. Each of the variables was mean-centered prior to forming the multiplicative term, to alleviate any multicollinearity (Aiken and West, 1991: Kmenta. 1986; Wasserman and Kutner, 1985). The Variance Inflation Factor (VIF) and tolerance were examined to verify that multicollinearity was not a problem in the analysis. Finally, plots of residuals were examined to confirm the normality of the residuals.

\section{Results}

Table 1 presents the descriptive statistics and correlations of the study's key variables. Table 2 reports the coefficient estimates for the main and interaction effects of the TMTs' external ties and board composition on the strategic choices of late movers at time $t+1$.

The base model includes the control variables. The second model includes both control and main variables. The results generally provide support for Hypotheses 1,2, and 3, which posit that there are direct effects of the TMTs external ties and board independence on the strategic choices of late movers. Although intra-industry importation was not significantly related to late movers' choice of strategy, consistent with expectations, intra-industry ties via participation of top managers in trade associations were negatively related to the adoption of a resource-substitution strategy by late movers $(\beta=-0.098, p<.01)$. Thus, when controlling for organizational factors, we found that top managers' participation in industry trade associations intensified the tendency of late movers to choose a resource-imitation strategy over resource substitution. In Hypothesis 2 , both types of extra-industry ties - those created through the importation of top managers from outside the focal industry (Hypothesis $2 a$ ), and top managers' participation in general professional associations (Hypothesis $2 b$ ) - exhibited positive relationships with the choice of a resource-substitution strategy $(\beta=0.167, p<.001$ and $\beta=0.091, p<.01$, respectively).

Hypothesis $3 a$ posited that the ratio of outsiders on the board was positively associated with the adoption of a resourcesubstitution strategy by late movers, as was board independence measured by the separation of the CEO and board-chair position. The inclusion of more outsiders on the board did not reveal a significant direct effect on the strategic choice of late movers. However, consistent with Hypothesis 3b, the separation of CEO and board chair duties exhibited a positive relationship with the choice of a resource-substitution strategy $(\beta=0.058, p<.05)$.

Two control variables measured at time $t$ had an effect on the strategic choices of late movers at time $t+1$. The regression results revealed a significant negative relationship $(p<.001)$ between firm size and resource-substitution strategy. which implies that the bigger the firm the more likely it is to emulate established industry practice. Strategy at time $t$ was found to be positively and significantly related to the strategy at time $t+1(p<.001)$. implying that strategic choices of late movers are characterized by an inertia - what they have done in the past is what they tend to do in the present.

Hypotheses 4 and 5 posited that two-way interactions existed in such a way that the strategic choice of top managers would be affected by monitoring by outsider-rich boards. Thus, interaction variables were entered into the second regression model. Overall, the third model makes a significant contribution over and above the previous model $\left(\Delta R^{2}=0.031, \mathrm{p}<.001\right)$. Given that the strategy of late movers was measured according to resource similarity with the first mover (i.e., higher scores mean more resource substitution), the expected sign for the interaction terms of intra-industry ties and board outsiders ratio is positive (i.e., intra-industry ties at $t$ are associated with the adoption of a resource-substitution strategy at time $t+1$ when the board-outsider ratio is high) while that for extra-industry ties is negative (i.e., extra-industry ties at $t$ are associated with the adoption of resource-imitation strategy at time $t+1$ when the board-outsider ratio is high).

Although the board-outsiders ratio did not significantly moderate the relationship between the TMTs participation in trade association and strategic choice, the interaction between the number of top managers hired from inside the focal

Table 1

Descriptive statistics and pearson correlations ${ }^{*}$

\begin{tabular}{|c|c|c|c|c|c|c|c|c|c|c|c|c|c|}
\hline Variable & Mean & S.D. & 1 & 2 & 3 & 4 & 5 & 6 & 7 & 8 & 9 & 10 & 11 \\
\hline 1. Strategy $(t+1)$ & 5.64 & 2.27 & & & & & & & & & & & \\
\hline 2. Intraindustry importation & 0.07 & 0.10 & 0.02 & & & & & & & & & & \\
\hline 3. Trade assocjation ties & 0.03 & 0.07 & -0.14 & -0.16 & & & & & & & & & \\
\hline 4. Extraindustry importation & 0.08 & 0.13 & 0.28 & -0.13 & 0.01 & & & & & & & & \\
\hline 5. Professional association ties & 0.05 & 0.14 & 0.22 & -0.15 & 0.07 & 0.39 & & & & & & & \\
\hline 6. Board outsiders ratio & 0.70 & 0.21 & -0.18 & -0.07 & -0.01 & 0.05 & 0.09 & & & & & & \\
\hline 7. Separate CEO-chair & 0.64 & 0.48 & -0.03 & $-0,06$ & -0.09 & -0.01 & 0.03 & -0.01 & & & & & \\
\hline 8. TMT tenure & 11.12 & 5.90 & -0.21 & -0.48 & 0.22 & -0.31 & -0.03 & 0.11 & -0.01 & & & & \\
\hline 9. Firm age & 32.70 & 26.68 & -0.32 & -0.22 & 0.04 & 0.02 & 0.06 & 0.34 & 0.21 & 0.36 & & & \\
\hline 10. Firm size & 7,26 & 1.76 & -0.50 & -0.17 & 0.05 & -0.21 & -0.16 & 0.31 & 0.14 & 0.50 & 0.48 & & \\
\hline 11. Strategy $(t)$ & 6.04 & 2.37 & 0.56 & 0.04 & -0.13 & 0.13 & 0.08 & -0.17 & -0.08 & -0.12 & -0.29 & 0.38 & \\
\hline 12. Diversification & 0.15 & 0.36 & -0.17 & -0.22 & -0.01 & -0.02 & 0.13 & 0.20 & 0.11 & 0.24 & 0.44 & 0.26 & -0.13 \\
\hline
\end{tabular}

d Correlations greater than .08 are significant at the .05 level; $\mathrm{N}=724$ 
Table 2

Elfects of the TMTs external ties and board composition on strategic choice $(\mathrm{N}=724)^{i}$

\begin{tabular}{|c|c|c|c|}
\hline & Model 1 & Model 2 & Model 3 \\
\hline Intra-industry importation & & $\begin{array}{l}-0.005 \\
(-0.16)\end{array}$ & $\begin{array}{l}-0.592 \\
(-5.58)^{\circ}\end{array}$ \\
\hline Trade association ties & & $\begin{array}{l}-0.098 \\
(-3.37)^{*}\end{array}$ & $\begin{array}{l}-0.191 \\
(-1.82)\end{array}$ \\
\hline Extra-industry importation & & $\begin{array}{l}0.167 \\
(4.98)^{* * *}\end{array}$ & $\begin{array}{l}0.495 \\
(4.59)^{\circ . *}\end{array}$ \\
\hline Professional association ties & & $\begin{array}{l}0.091 \\
(2.92)^{*}\end{array}$ & $\begin{array}{l}0.145 \\
(1.21)\end{array}$ \\
\hline Board outsiders ratio & & $\begin{array}{l}-0.006 \\
(-0.21)\end{array}$ & $\begin{array}{l}-0.087 \\
(-2.09)^{4}\end{array}$ \\
\hline Separate CEO-chair & & $\begin{array}{l}0.058 \\
(2.00)^{*}\end{array}$ & $\begin{array}{l}0.053 \\
(1.84)\end{array}$ \\
\hline Intra-industry importation $\times$ Outsider ratio & & & $\begin{array}{l}0.621 \\
(5.80)^{* \ldots *}\end{array}$ \\
\hline Trade association ties $\times$ Outsider ratio & & & $\begin{array}{l}0.094 \\
(0.89)\end{array}$ \\
\hline Extra-industry importation $\times$ Outsider ratio & & & $\begin{array}{l}-0.344 \\
(-3.10)^{\circ}\end{array}$ \\
\hline Professional association ties $\times$ Outsider ratio & & & $\begin{array}{l}-0.038 \\
(-0.31)\end{array}$ \\
\hline TMT tenure & $\begin{array}{l}0.024 \\
(0.70)\end{array}$ & $\begin{array}{l}0.106 \\
(2.58)^{*}\end{array}$ & $\begin{array}{l}0.125 \\
(3.12)^{* *}\end{array}$ \\
\hline Firm age & $\begin{array}{l}-0.044 \\
(-1.23)\end{array}$ & $\begin{array}{l}-0.103 \\
(-2.86)^{\circ}\end{array}$ & $\begin{array}{l}-0.112 \\
(-3.16)^{\circ}\end{array}$ \\
\hline Firm size & $\begin{array}{l}-0.319 \\
(-8.47)^{*}\end{array}$ & $\begin{array}{l}-0.292 \\
(-7.64)^{\prime \ldots}\end{array}$ & $\begin{array}{l}-0.315 \\
(-8.24)^{*}\end{array}$ \\
\hline Strategy $(t)$ & $\begin{array}{l}0.429 \\
(13.65)^{* * *}\end{array}$ & $\begin{array}{l}0.393 \\
(12.76)^{\ldots *}\end{array}$ & $\begin{array}{l}0.358 \\
(11.57)^{* \ldots}\end{array}$ \\
\hline Diversification & $\begin{array}{l}-0.012 \\
(-0,37)\end{array}$ & $\begin{array}{l}-0.032 \\
(-1.01)\end{array}$ & $\begin{array}{l}-0.008 \\
(-0.271)\end{array}$ \\
\hline $\begin{array}{l}R^{2} \\
F \text {-statistic } \\
\Delta R^{2} \\
\text { Change in } F\end{array}$ & $\begin{array}{l}0.410 \\
99.75^{* \cdots}\end{array}$ & $\begin{array}{l}0.461 \\
55.26^{*} \\
0.051 \\
11.145^{\circ}\end{array}$ & $\begin{array}{l}0.492 \\
45.66^{\circ \cdots} \\
0.031 \\
10.856 * *\end{array}$ \\
\hline
\end{tabular}

"p $<.05 ; " * p<.01 ; * " p<.001$.

" Standardized regression coefficients are reported. T-test results are in parentheses.

industry and the board outsider ratio was significant, and in the expected direction. Specifically, a positive significant relationship $(\beta=0.621, p<.001)$ was observed for the intra-industry importation and the ratio of board outsiders, indicating that top managers imported from inside the focal industry opt for a resource-substitution strategy over resource imitation when they work with an outsider-rich board. Thus, the results provide support for Hypothesis $4 \mathrm{a}$. Figure 1 is a graphic representation of this interaction effect.

The multiple regression results also provide partial support for the moderating effects of board outsiders on the relationship between the TMT's extra-industry ties and a resource-substitution strategy. The regression coefficient for the interaction between the TMTs professional association ties and the ratio of outsiders was not statistically significant at conventional levels, but it was in the expected direction. However, as expected in Hypothesis 5a, there existed a significant, negative relationship for extra-industry-importation ties with the ratio of outsiders $(\beta=-0.344, p<.01)$. This finding implies that the tendency of top managers imported from outside the focal industry to adopt a resource - substitution strategy changed to a resource-imitation strategy when they work with an outsider-rich board. This interaction effect is illustrated in Figure 2.

\section{Discussion}

We used a multiyear sample of first and late movers in the computer industry to explore the relationship among TMT external ties, board composition, and selected strategy in late movers. In the first stage of our analysis on main effects we found support for the contention that intra-industry trade-association ties promoted the use of a resource-imitation strategy, but our results for hiring managers from inside the industry, although in the predicted direction (i.e., a preference for resource imitation) were not significant. However, we did find strong support for the prediction that both hiring managers from outside the industry and the TMT's participation in professional associations would lead to the adoption of a resourcesubstitution strategy. Our findings showed that a simple preponderance of outsiders on the board did not lead to adoption of a resource-substitution strategy, but separating the role of CEO and board chair did. Thus, the post-Enron, post-Worldcom, post-Rite-Aid calls from the NYSE for separation of roles is valid. Our findings suggest that duality leads to a preference for resource imitation, but that separation of the roles frees the board from the dominant influence of an insider chair. 


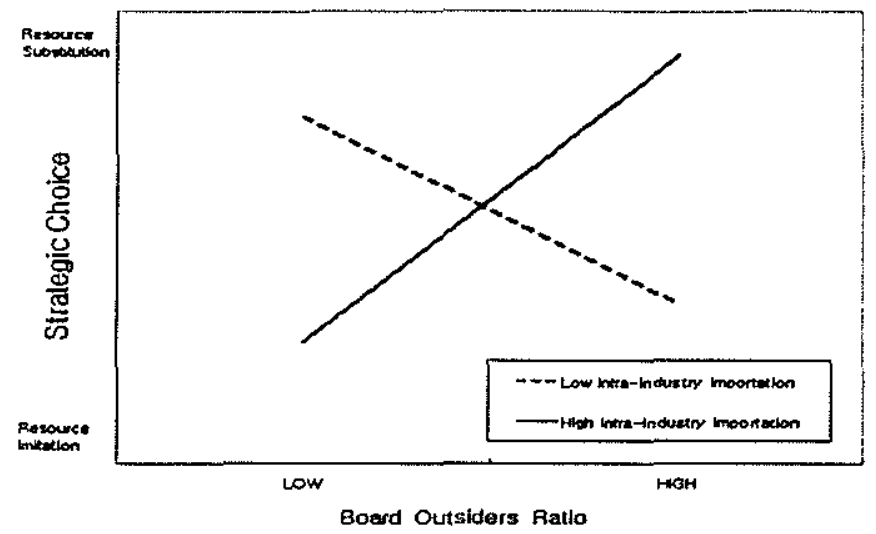

Figure 1. Interaction effect of TMTs intra-industry importation ties and board outsider ratio

This work parallels that of Geletkanycz and Hambrick (1997) and Yoo and colleagues (2009) insofar as we examined the boundary-spanning activities of executives and how that related to firm outcomes (Geleckanycz and Hambrick, 1997 ; Yoo et al., 2009). But it also extends those earlier works because it addresses the issue of the effects of board independence and board-and-TMT interactions. The second stage of our analysis revealed that in firms with outsider-rich boards the natural inclination of those managers who select a strategy of imitation, and those who prefer a strategy of substitution, is reversed. We can thus deduce that the monitoring and control function provided by outsiders reduces agency problems caused by managers selecting strategies which favor the protection of their employment capital rather than ones that generate returns to stockholders.

Decision management naturally is the responsibility of senior management, whereas decision control becomes the responsibility of the board of directors, so in combination they reflect the interactions between the board and top managers. Despite this, little effort and attention has been devoted to developing a formal model of the interaction between top managers and boards. This study has generated much-needed empirical evidence on the topic. Our work is thus complementary to the existing body of knowledge on board composition and leadership structure which is core to the literature on corporate governance. Our work lends empirical support to the theoretical arguments long made on the importance of having a preponderance of outsiders on the board. It also lends empirical support to the idea that separating the roles of CEO and board chair is important for board power. By looking at the interaction between the board and the TMT, our analysis also confirms the importance of the agency view of governance: monitoring and control is an important task for the board. What our work does not do is link this interaction (or the main effects) to subsequent financial performance. Where we have focused on governance and strategy, the next obvious step for research is to explore what superior monitoring and control, and reduced agency costs, mean for firm performance.

Because of the potential for statistical noise in our analysis, we selected a parsimonious research design which focused on the strategy of late movers. The imitation-substitution continuum that describes late-mover strategy provides a simple but powerful mechanism for observing the effects of changes in our independent variables, board composition and leadership structure. We can think of no reason why the design should create a boundary condition which restricts our findings to the actions of late movers. They should also apply to first movers. However, to verify that the research should be repeated, using first-mover strategy as a dependent variable.

There are two key implications for practice. Firstly, the monitoring-and-control function of the board manifests itself through the interaction with the TMT. That is important in the stewardship the board provides for the owners. In particular, as the ratio of outside directors to total board members increases, there is a higher probability of the board ensuring that managers are taking the risks necessary to provide the best returns for shareholders. Thus, when enlarging the size of the board, appointment from outside rather than inside should be the rule. Secondly, in the full model, our results did not reveal an interaction effect between board composition and the TMTs external ties on selected strategy. Why that should be so is not clear and we hesitate to suggest that these industry ties are not important. Instead, we simply deduce that the hiring of senior managers and the selecting of board members needs to be done relative to each others' knowledge and experience, rather than simply focusing on current contacts.

\section{Limitations}

Like most research, this study has a number of limitations. First, the use of secondary data means we were unable to identify motivations for forming external ties. We assumed a link between external ties and the formulation and implementation of strategies, but other motivations may exist. For example, boundary spanning can be used for accessing critical resources; for interorganizational power; for organizational legitimacy; for organizational learning; as well as organizational 


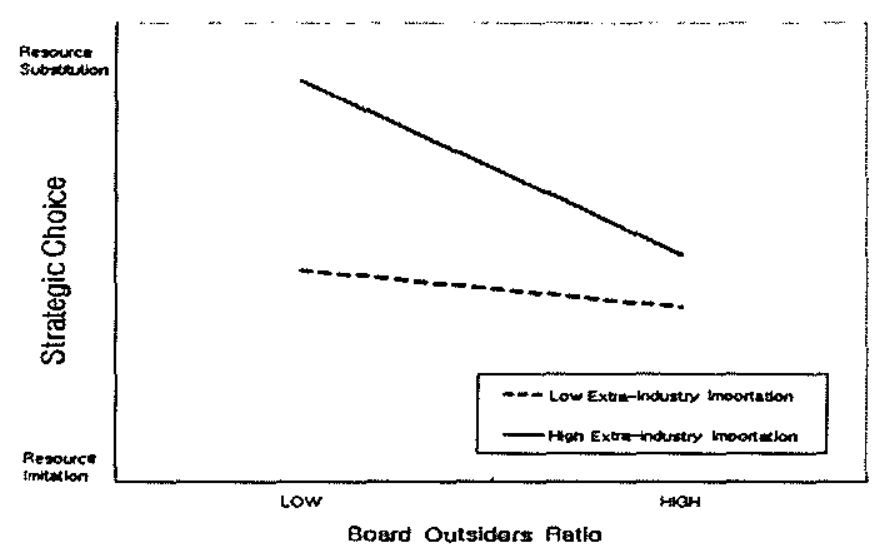

Figure 2. Interaction effect of TMTs extra-industry importation ties and board outsider ratio

prestige (Galaskiewicz, 1985; Levitt and March, 1988; Pfeffer, 1987; Westphal et al., 2006). These motivations may create noise in the ties-strategy relationship and thus need addressing in future studies. Secondly, the finer details of social networks, such as frequency and strength of interaction in the social ties, were beyond the scope of this work. Finally, we did not control for TMT demographic heterogeneity. It has been found that TMT heterogeneity provides a wider range of perspectives (Wiersema and Bantel, 1992). In terms of limitations for this work, a wide range of perspectives might have influenced the strategic choices of our sample firms; that is, the more heterogeneous the TMT of late movers, the more likely they would be to choose a strategy of resource substitution over resource imitation.

\section{Conclusion}

The job of the board is to ensure that the owners' interests are being protected. This work has shown that a preponderance of outsiders on the board is a prerequisite for ensuring that outcome occurs. Also, separating the duties of CEO and chairman helps ensure that the board has the power necessary to perform the control part of their monitor-and-control task. Finally. despite the extensive array of extant research, it is clear more insights into the interaction between the board and top management are required if we are to fully understand how to manage the agency issues which still exist. This research has helped move us toward that goal.

\section{Acknowledgements}

This paper was supported by Konkuk University in 2012 .

\section{References}

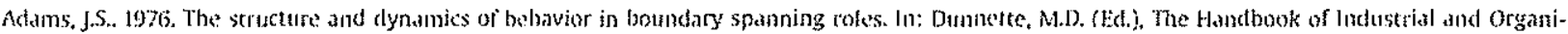
zational Rsychology. Rand MeNially, Chicigb. pp. 1175-1199.

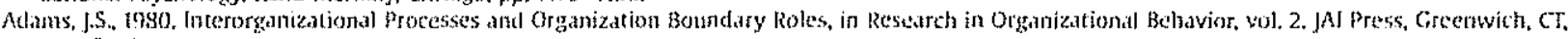
pp. 321-35.

tiken, L.S., West, S.G., 199I. Muttiple Rezression: Testing and Iriterpreting Intemetions. Sage, Thousand Oaks. CA.

Aidrich. H., l'fe[fer, J., 1975. Fubironments of organizations. Annial Review of Sociology $2.79-105$.

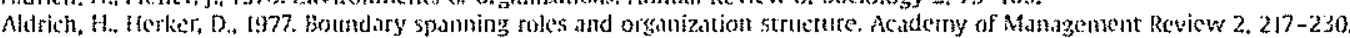

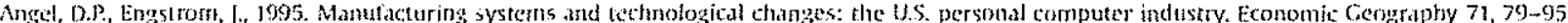

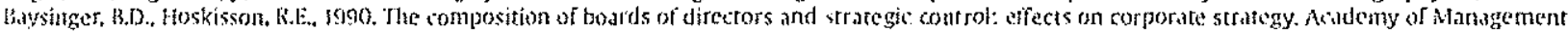
Revic'w 15, 72-87.

Berle, A.A. Means, G,C. 1932. The Modern Corporation and Private Property. HacMillan, New York.

Burr, R.S., 19883. Corporate Prolits and Coopration. Academic Press, New York.

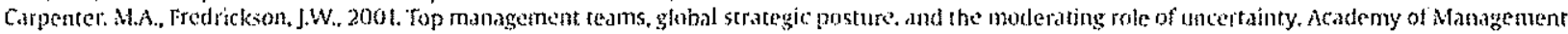
Journd $44,533-5-5$ ils.

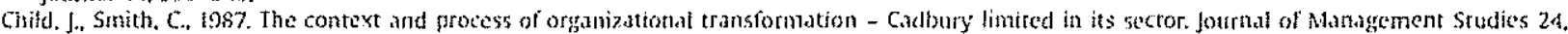
$565-593$.

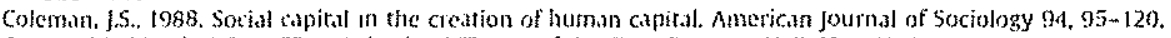

Cyert. R.M., March. J.G., 1963. A gehavioral Theory of the Finm. Prentice-Jall. New York.

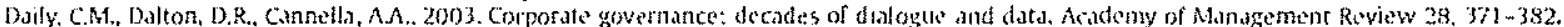

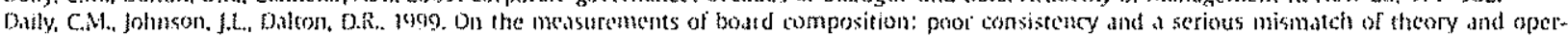
ationalization. Decismon Sonences $30.83-106$.

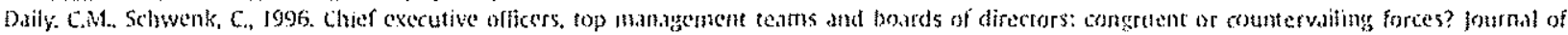
Ningagement 22, 185-202.

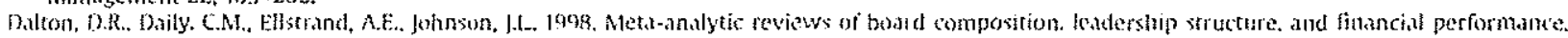
Strategric Mrandzement joumal $19,269-290$.

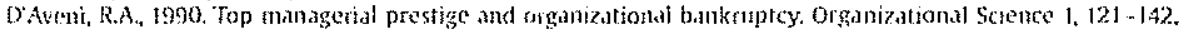


Davis, G.F. Diekmann, K.A. Timsley. C.H., 1004. The decline and tall of the conglomerate firm in the 1980s: the deinstitutionalization of an organizationa! ionn. American Sociologrical Review 59. $547-570$.

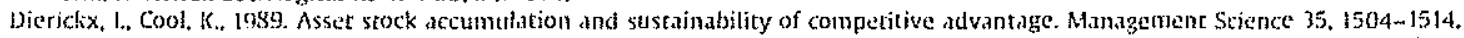

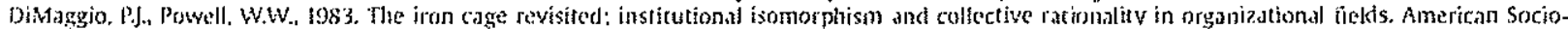
iogical Review $48,147-150$.

Durbin, 1. Watson, G.S., 1950. Testing for serial correlation in least squares regression. I. Biometrikn 37. 409-428.

Durbin, J., Watson, C.S., 1951. Tescing for serifit eorrelarion in feast squares reygression, lI. Biometrika 38, 159-179.

Eisenminn, T.R., 2002. The effects of CEO equiry ownersfip and tirm diversification on risk taking. Strategie Manigement Journal 23, 513-534.

Fame. F., 1980. Agency problens and the theory of the firm. Jutrmal of folitical Economy $88.288-307$.

Fam. E. jensen, M.. 1983. Separation of ownership and control. journal of Law and Econonics $26,301-32.5$.

Ferrier, W.J., Lec, H.. 2002. Strategic aggressiveness, variation, and surprise: how the sequential pattern of competitive rivalry influences stock matket feturns. Journal of Maladgerial lssues 1.4, 162-130.

Finkelsteia, S. Hambrick. D.C.. 1990 . Tup-managgentent team tenure dnd organizational ottcomes: the moderating mole of managerial diseretion. Admin. iscrative: Science Qunterly $35,484-503$.

Finkeistein, S., Hambrith. D.C. 1996. Stracegic Leadership: Top Executives and Their Fffects on Organizations. West Publislzing Company. St. I3ul, AN.

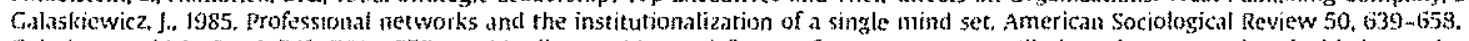

Geletkanyez. M.A., Boyd, B.K., 2611. CEO outside difecorships and firm performance: a reconciliation of agency dend embeddedness views. Academy of Mandxement joursial 54, 335-352.

Celarkanycz. HA. Hambrick. D.C. 1997. The external ties of top cxecutives: implicarions for strategic thoice mo performule. Administrative Science 2uarterly $42,654-681$.

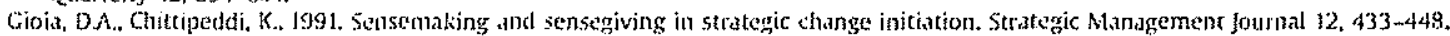

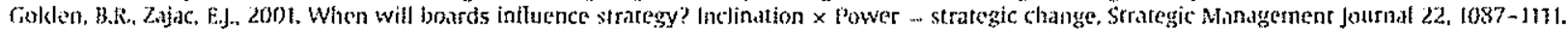

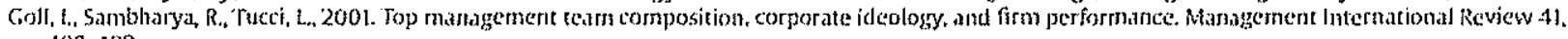
$109-129$.

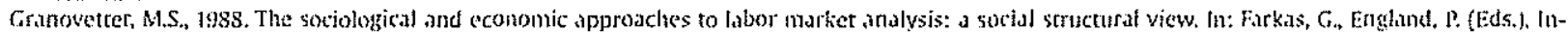
duscries. Firms, and Jobs: Sociological and Econonic Approacl. Plenum, New York. pp. 18 's-217.

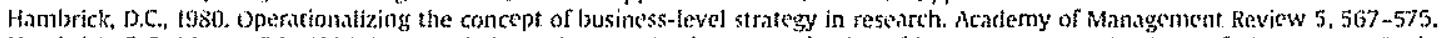

Hambrick. D.C., Mason, P.A. 1984. Upper echelons: the orgatization as a reflection of its top managers. Academy of Mantigement Review $9.193-206$.

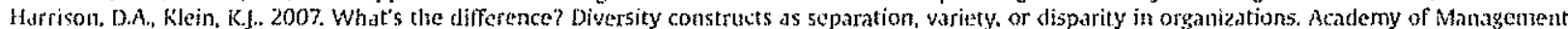
Revicw 32.1199-1228.

Hatnsclaild. P.R.. 9993. Interorgenizational imitation: the impet of intertocks on corpotate acquisition activity. Adninistrative Stience Quarterly 28. $554-5 ! 2$.

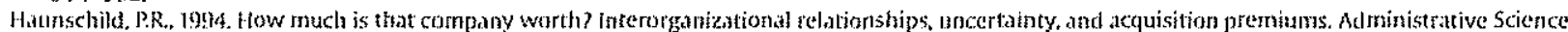
Quarturly 319. $391-411$.

Helventan. H.A. 1992. Between a tock and a hard place: organizational dhange and performance conder conditions of fundamental environmental translomation. Aduinistrative Srience Quarterly $77.48-57$.

Hendry. K.P., Kiel, C.C., Nichulson, G., 2010. How boutls strategize: a straltegy as practice view. I.ong Range Planning 43, 33-56.

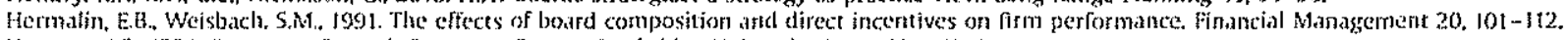

Herman, E.\$. 1981. Corponte Control, Corponate Power. Cambridge University Press, New York.

Hunt, S.b., 2000. A Ceneml Theory of Comperition: Resources, Competences, Productivity. Economic Growth. Sage, Thousand Oaks, CA.

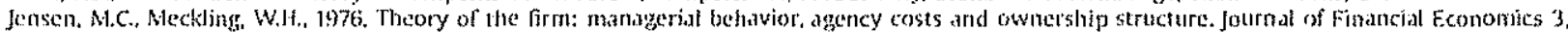
$305-360$.

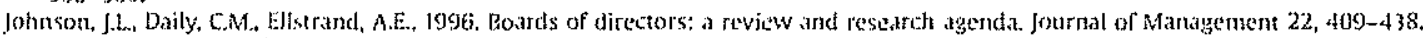

Judge, G.C., Hill, C.R. Gritiths, W.E., L.utkepoht, H., Lee. T., 1982, Introduction to the Theory and Practice of Econometrics. Wikey, New York, NY,

judge, W.Q, Zeithaml, C.P., 1992. fnstitutional and strategic choice perspectives on brald involvement in the strategic decision protess. Academy of Mandgement Joutmal 35, $766(3-794$.

Kesner. I.R. IOS8. Dinetor chafacteristies and committes membership: an investigation af type, accupation, tenture, atd gender. Academy of Management foumal $31,65-94$

Kuntuta, J., 1986, Elements of Econometrics. Macmillan, New York, NY.

Kor, Y.Y., 2003. Experience-based top mandegenent team competence and susrained growth. Organization Science $14,707-719$.

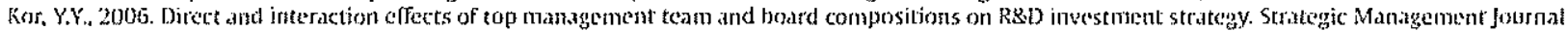
27. 1081-1099.

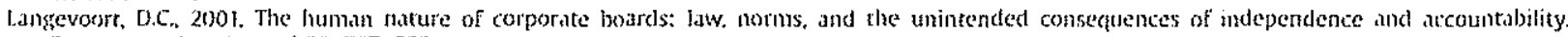
Crorgetown Law Journal $\$ 20,797-832$.

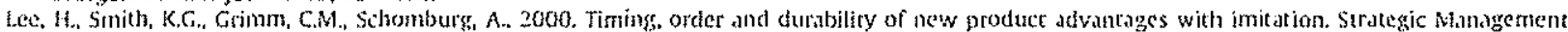
Journal 21, 23-30.

L.evitt. F, March. J.G. 1988. Organizational liarning. Annual Review of Sociology $14,319-340$.

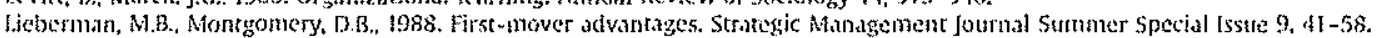

March, I.G., Simon, H.A. 1058. Orgatizations. Wiley, New York.

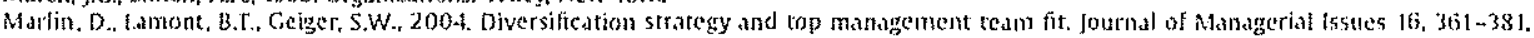

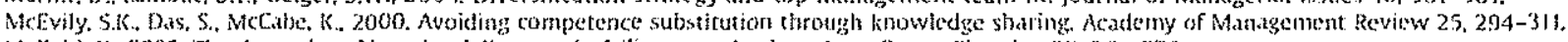

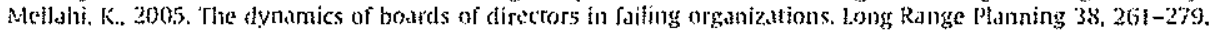

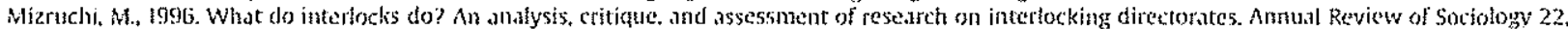
$271-298$.

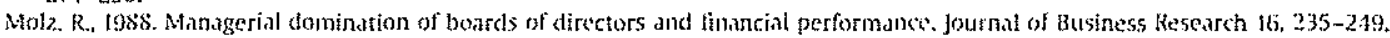

Motck, R., Shleiter, A. Vishny. R.W., 1989. Alternalive mechanisms for corporate control. American Economic Rivicw 79, 8-12-852.

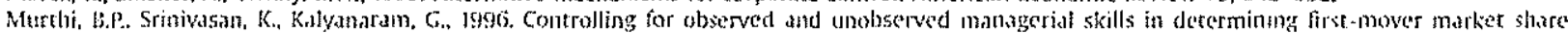
advantages. Journal of Marketing Research $33.329-336$.

Nelson, R.R., Winter. S.G., 1982. An Evolettionary Theory of Fconouic Ch,ange. Harvard University fless. Camitoridge. MA.

ONeal, D.. Thomas, H. 1999. Developing the striltegic board. long Range Planning 29. 314-327.

Patton, A., B.iker. J.C. 1987. Why wont directors rock the boat. Harvard Business Review 65. 10-18.

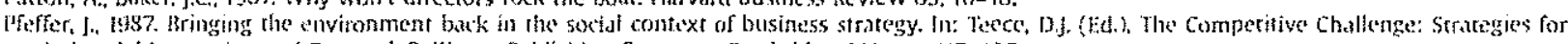
Industrial innovation and Renewal. Ballinger Publishing Company, Cambridge, MA, pp, 117-135.

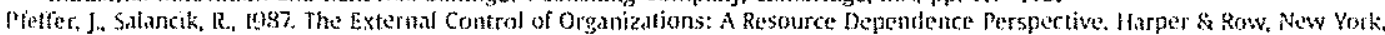

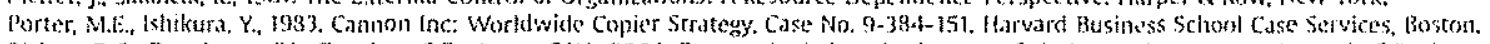

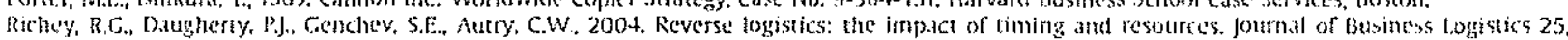
$229-250$.

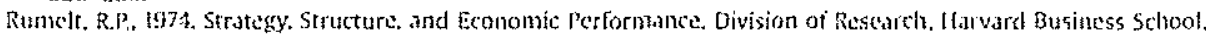

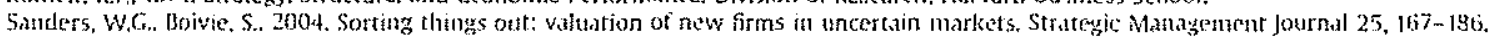




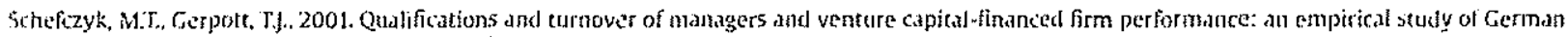
venture capital-investments. Joumal of Business Venturing 16. 1-4.5-163.

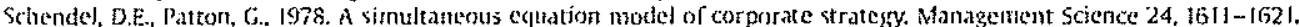

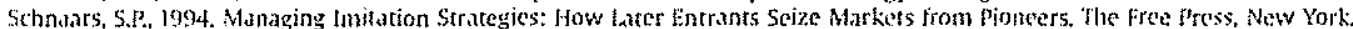

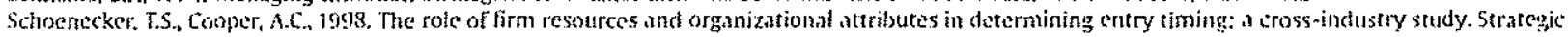
Minugement Journal 19, 1127-1143.

Scott. W.R., 1985. Conllicting levels of rationality: regulators, mantagers, and professionals in rhe medicat care secror. Journal of health Administration and Education 3, 113-131.

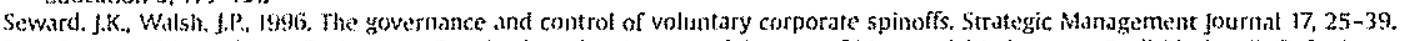

Spender. J.C. 1989. Industry Recipes: An Enulity into the Naftere and Sources of Managerial fudgement. Basil Blackwell, Oxford.

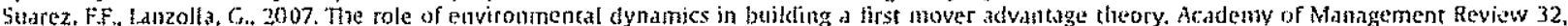
$377-392$.

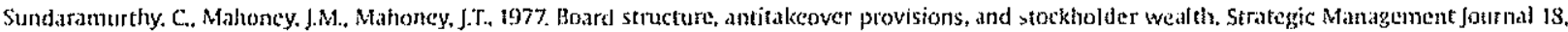
$231-245$.

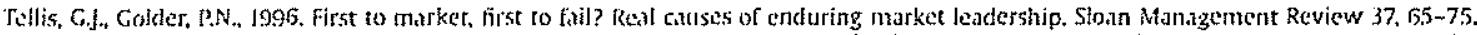

Virany, B. Tushman, V.L. Romanelfi, E., 1992. Executive succession and orgabization outcomes in turbulent environments: an organization learning approaclu. Organization Science 3, 72-91.

Wassermarl, J.N. Kutner, M., 1985. Applied Linear Stutistital Miodels. Richard D. [rwin, inc

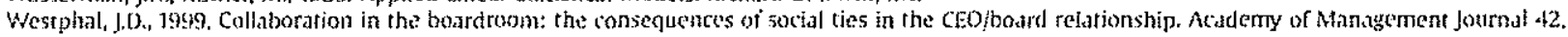
$7-24$.

Westplat, 1.D., Boivie, S. Chung. D.h.M. 2005. The strategic impetus for social network tios: reconstituting broken CEo friendsing ties. Strategic Man . deremenc Jouran! $27.425-44.5$.

Westphal, 1.0. Fredrickson, 1.W. 200t. Who directs strategic elange? Ditector experience, the selection of new CEOs, and chatge in corporate strategy. Strategic Mandzement Journal $22.1113-113 \%$.

Westphat, J.D. Zajac, E.J. 1995. Who shall govern? CEO/bodal power, demographic similarity. and new director selections. Adminiscrative Scjence Guarterly $40,60-83$.

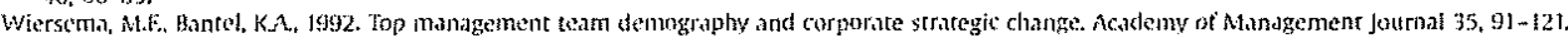

Wikhund. 1. Shepherd, D., 2003. Knowledge-based resources, entrepreneurial orientation, and the performance of smatl and mediurn-sized busifesses. Strategic Management lournal $24,1307-131-4$.

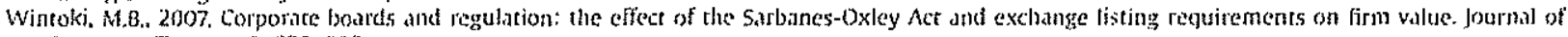
Corporate Finance $13,299-250$.

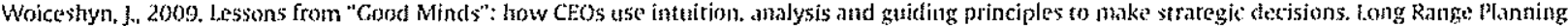
$42,298-319$.

Wu, H.L, 2003. How do board-CEO relationships influence the performance of new product introtertion? Mfoving from single co interdependent explanations. Corporite Covernance: An International Revícw $15,77-89$.

Yoo, JW. Reed. R. Shin, S.J. L.mak, D.J. 2000. Strategic choice and performance in hate movers: influence of the top mandgement team's externat ties. Jourtind of Management Srudies $46,308-335$.

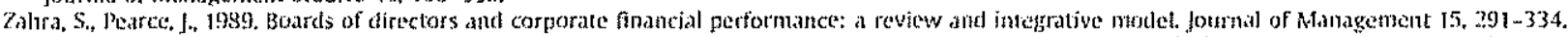

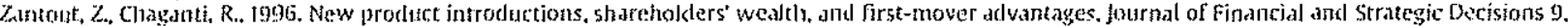
$49-51$.

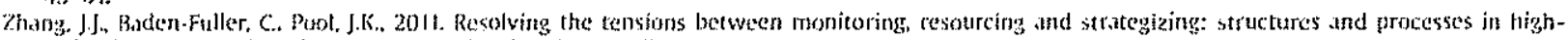
tochnofrgy vanture boards, long Range l'laming 44, 95-117. 